\title{
Mast cell mediated ion transport in intestine from patients with and without inflammatory bowel disease
}

S E Crowe, G K Luthra, $M$ H Perdue

\begin{abstract}
Background-Mast cells have been shown to regulate intestinal ion transport in animal models and normal human colon but their physiological role in human intestinal inflammatory disorders is unknown. Aims-To examine mast cell regulation of ion transport in inflammatory bowel disease (IBD).

Subjects and methods-Small and large intestine was obtained from patients with and without IBD undergoing surgical resection. Short circuit current (Isc) responses to rabbit antihuman IgE, histamine, and electrical stimulation were measured in Ussing chambers. Specimens were also examined for mast cell numbers and degree of inflammation.

Results-Isc responses to anti-IgE and histamine were smaller in magnitude in IBD compared with non-IBD tissues. In all tissues, anti-IgE Isc responses were reduced by about $80 \%$ in chloride free buffer. The histamine $\mathrm{H}_{1}$ receptor antagonist, pyrilamine, decreased anti-IgE responses in non-IBD tissues. Greater inhibition with pyrilamine was seen in IBD small intestine but its effect was less in IBD colon. Histamine pretreatment of non-IBD control tissues reduced anti-IgE responses to levels seen in IBD colon but had no effect in small intestine. Mast cell numbers were greater in IBD compared with non-IBD small intestine while no differences were observed between the colonic groups. Isc responses to anti-IgE were not correlated with the degree of mucosal inflammation.

Conclusions-This study provides further evidence that mast cells are capable of mediating alterations of ion transport in human gut but that this regulatory role may be altered in IBD. The data suggest that prior activation of mast cells with release of histamine may account for the reduced secretory response to anti-IgE observed in IBD colonic tissues. (Gut 1997; 41: 785-792)
\end{abstract}

Keywords: mast cells; intestine; ion transport; histamine; ulcerative colitis; Crohn's disease

Mast cells are found within all layers of the gut wall throughout the gastrointestinal tract. By virtue of the large number of biologically active substances they release, ${ }^{1}$ mast cells have great potential to influence gut function, including fluid and electrolyte transport. Animal studies clearly demonstrate that mast cell activation alters intestinal epithelial ion transport ${ }^{2-4}$ and more recently, we and others have confirmed similar events in human intestine. ${ }^{56}$ Activation of mast cells using antibodies directed against surface immunoglobulin $\mathrm{E}$ ( $\mathrm{IgE}$ ) resulted in a chloride secretory response that involved histamine, eicosanoids, and enteric nerves. ${ }^{56}$

That mast cells may regulate gut function is important since intestinal mast cells have been implicated in the pathogenesis of a number of conditions including inflammatory bowel disease (IBD), coeliac disease, food allergy, and systemic mastocytosis. ${ }^{7}$ Evidence for their role in IBD includes increased numbers of mast cells, ${ }^{8-11}$ including degranulated mast cells ${ }^{12}{ }^{13}$ in IBD intestine as well as elevated levels of histamine measured in the gut lumen of patients with IBD. ${ }^{14}{ }^{15}$ Enhanced release of histamine and eicosanoids has also been described in actively inflamed IBD tissues after isolated intestinal mast cells were stimulated by crosslinking IgE receptors. ${ }^{16}{ }^{17}$ The functional significance of mast cells in IBD has not been examined in the context of the intestinal epithelium however.

In this study epithelial short circuit current (Isc) responses to rabbit antihuman IgE and to histamine were studied in isolated human intestine mounted in Ussing chambers. Secretory responses were compared in large and small bowel from patients with and without IBD. Pyrilamine, a histamine $\mathrm{H}_{1}$ receptor antagonist, and histamine desensitisation were used to investigate the mechanisms underlying altered mast cell mediated intestinal ion transport in IBD tissues.

\section{Materials and Methods}

PATIENT SPECIMENS

Small and large intestinal tissues were obtained from 159 patients undergoing elective bowel surgery over a five year period at McMaster University Health Sciences Center. Sixty five of these patients had inflammatory bowel disease ( 14 with a diagnosis of ulcerative colitis and 51 with Crohn's disease) diagnosed by standard clinical, radiological, endoscopic, and histological criteria. Indications for intestinal resection in patients with IBD included manifestations of intestinal disease unresponsive to medical therapy (for example, diarrhoea, anaemia, strictures, fistulas), intolerance of medical therapy, and colonic dysplasia. The medical 
conditions requiring removal of large and/or small intestine in the 94 patients without IBD were mainly colorectal adenoma/carcinoma, diverticular disease of the colon, pancreatic cancer, and malignancies of the small intestine. Tissues obtained from patients with bowel tumours were procured from areas well removed (more than $5 \mathrm{~cm}$ ) from the tumour margins. In general, specimens provided by the pathologist for laboratory use were free of gross disease including ulcers, strictures, and other specific lesions. The study was conducted with the approval of the McMaster University Ethics Committee.

Segments for experimental use were cut from the resected surgical specimens by a pathologist and then transported in oxygenated Krebs buffer to the Intestinal Disease Research Unit laboratory. The specimens were then prepared by removing the muscularis propria before mounting in Ussing chambers or fixing for histological assessment. For most resected specimens, it was possible to mount adjacent tissues in four Ussing chambers. The total time from resection in the operating room until the tissues were mounted in the chambers was approximately 30-45 minutes.

Specimens were categorised as being from the small or large intestine in patients with and without IBD. All small intestinal IBD specimens were from the distal ileum of patients with Crohn's disease. The majority of the nonIBD small bowel cases also involved the terminal ileum. Large bowel specimens included tissues from all regions of the colon. Large intestinal tissues were grouped as ulcerative colitis, Crohn's disease, or non-IBD. We have previously shown that colonic tissues subgrouped according to two main associated pathological conditions (colorectal polyps or cancer and diverticular disease) do not exhibit differences with regard to mast cell numbers or response to anti-IgE stimulation. ${ }^{5}$ Thus, all non-IBD colonic tissues were grouped together for the purposes of this study. The medical record including the final surgical pathology report was used to confirm the preoperative/intraoperative diagnosis in each case.

The results reported in this study were obtained from experiments using large and small intestinal tissues from 68 patients without IBD, 45 with Crohn's disease, and nine with ulcerative colitis. Some patients were the source of more than one type of tissue if both large and small intestine were removed from an individual subject. Tissues from 27 patients without and 14 with IBD were excluded from the final analysis based on: the failure of the baseline Isc to stabilise; the absence of a detectable basal Isc or potential difference (PD); or the lack of response to $10^{-5} \mathrm{~mol} / 1$ forskolin, a cAMP mediated secretagogue added at the end of the experiment to assess non-receptor mediated intestinal epithelial secretion (see below). A response to forskolin less than $10 \mu \mathrm{A} / \mathrm{cm}^{2}$ became a criterion for excluding tissues after preliminary experiments showed that many of these tissues failed to respond to anti-IgE or histamine in spite of a reasonable baseline Isc and PD. In many of these cases of exclusion, the time from surgical removal until mounting in the chambers was prolonged.

\section{USSING CHAMBER STUDIES}

Segments of intestinal mucosa were mounted in modified Ussing chambers exposing a surface area of $0.6 \mathrm{~cm}^{2}$ to $10 \mathrm{ml}$ Krebs buffer with $10 \mathrm{mmol} / 1$ glucose on the antiluminal (serosal) side and $10 \mathrm{ml} \mathrm{Krebs}$ buffer containing $10 \mathrm{mmol} / 1$ mannitol on the luminal (mucosal) surface. The Krebs solution containing (in mmol/1) $115 \mathrm{NaCl}, 8.0 \mathrm{KCl}, 1.25$ $\mathrm{CaCl}_{2}, 1.2 \mathrm{MgCl}_{2}, 2.0 \mathrm{KH}_{2} \mathrm{PO}_{4}$, and 25 $\mathrm{NaHCO}_{3}$ was maintained at $37^{\circ} \mathrm{C}$. Chloride free buffer containing (in mmol/l) $116 \mathrm{Na}$ isethionate, $4.6 \mathrm{~K}$ acetate, $1.5 \mathrm{Ca}$ acetate, 1.2 $\mathrm{Mg}$ acetate, $22 \mathrm{NaHCO}_{3}$, and $1.2 \mathrm{NaH}_{2} \mathrm{PO}_{4}$ was used instead of Krebs buffer in some experiments. The electrical PD across the preparation was measured by agar bridges connected to calomel electrodes. An automatic voltage clamp (World Precision Instruments, New Haven, Connecticut) was used to clamp the tissues at zero volts. The $I \mathrm{sc}$ (in $\mathrm{mA} / \mathrm{cm}^{2}$ ), a measurement of net ion transport, was recorded continuously, apart from readings of open circuit PD (in $\mathrm{mV}$ ) which were made every 10 minutes throughout the experiment. Measured Isc and PD values were used to calculate conductance ( $\mathrm{G}$, in $\mathrm{mS} / \mathrm{cm}^{2}$ ) using Ohm's law $(\mathrm{V}=\mathrm{IR})$. Tissues were allowed to reach a stable Isc before any stimulation was carried out.

\section{RESPONSES TO STIMULATION}

Anti-IgE

Rabbit antihuman IgE serum or control rabbit serum (both Dimension Laboratories, Mississauga, Ontario, Canada) was added to the serosal surface of intestine mounted in Ussing chambers. In previous studies, anti-IgE added to the luminal (mucosal) surface of intestinal tissues had no effect. ${ }^{5}$ Differences between the basal Isc and the increase in Isc observed after serum was added $(\Delta I \mathrm{sc})$ were calculated at one minute intervals for the first 15 minutes and at 20 minutes after anti-IgE stimulation. Peak Isc values were recorded to determine the maximum $\Delta$ Isc. Anti-IgE $10 \mu \mathrm{g} / \mathrm{ml}$ was used in all experiments based on results from previous dose response studies. ${ }^{5}$

\section{Histamine}

In some tissues histamine (Sigma Chemical Co., St Louis, Missouri) was added to the serosal side of intestinal tissues at a concentration of $10^{-4} \mathrm{~mol} / 1$ once the Isc had restabilised after adding anti-IgE. The response to histamine, $\Delta I$ sc, was determined at one minute intervals for 10 minutes after addition.

In other experiments, $10^{-4} \mathrm{~mol} / 1$ histamine was added twice (10 minutes apart) to non-IBD small or large intestinal tissues in Ussing chambers. Preliminary studies confirmed that this protocol was sufficient to inhibit Isc responses to subsequent challenge with histamine, but not forskolin, and was then 
used to compare Isc responses to anti-IgE in IBD and histamine pretreated non-IBD tissues.

Forskolin

At the end of each experiment, after the Isc had stabilised following any prior stimulation, $10^{-5}$ $\mathrm{mol} / 1$ forskolin (Sigma), prepared in dimethylsulphoxide, was added to the mucosal and serosal sides of the preparation. This concentration of forskolin has also been used to assess ion transport in human rectal suction biopsy samples. ${ }^{18}$ Responses ( $\left.\Delta I \mathrm{sc}\right)$ were calculated as the difference between the basal Isc and the maximum Isc seen after adding forskolin.

PHARMACOLOGICAL INHIBITOR/ANTAGONIST STUDIES

In these experiments, adjacent pieces of intestine from a single surgical specimen were mounted in the chambers. Whenever possible, two tissues were used as untreated controls and the other two tissues were treated separately with the pharmacological agent added to the serosal side of the intestinal preparation 15 minutes before anti-IgE. Pyrilamine (Sigma), a histamine $\mathrm{H}_{1}$ receptor antagonist, was dissolved in water and used at a concentration of $10^{-4} \mathrm{~mol} / \mathrm{l}$, a dose previously shown to inhibit ion transport responses to histamine in normal human colon. ${ }^{5}$

HISTOLOGY

Whenever the size of the experimental specimen permitted, a piece of intestine taken adjacent to the segment used for the transport studies was processed in our laboratory for histological assessment. Segments were fixed in formalin and stained with haematoxylin and eosin for assessment of mucosal architecture and inflammation. Adjacent segments were also fixed in Carnoys fixative for 24 hours followed by $70 \%$ ethanol before staining with toluidine blue at low $\mathrm{pH}$ and an eosin counterstain for mast cell quantitation. In addition to these sections, routine haematoxylin and eosin stained sections obtained for diagnostic purposes by the Pathology Department at McMaster University Health Sciences Center were also available for assessment.

Histological sections were examined by light microscopy. Standard criteria were used to identify acute or chronic mucosal inflammation as well as crypt architectural changes typical of IBD. ${ }^{19}{ }^{20}$ Inflammation was graded on a scale from 0 to 3 by a single observer unaware of the underlying clinical diagnosis or the elec-

TABLE 1 Baseline electrophysiological parameters in specimens grouped by site and associated pathological condition

\begin{tabular}{llrlll}
\hline Specimen site & Pathological condition & $n$ & Isc $\left(\mu \mathrm{A} / \mathrm{cm}^{2}\right)$ & $P D(\mathrm{mV})$ & $G\left(\mathrm{mS} / \mathrm{cm}^{2}\right)$ \\
\hline Small bowel & & & & & \\
& Non-IBD & $79(22)$ & $67.0(4.0)$ & $3.5(0.3)$ & $22.9(0.8)$ \\
Large bowel & Crohn's disease & $125(30)$ & $63.6(2.7)$ & $3.5(0.2)$ & $19.6(0.5)^{\star \star}$ \\
& & & & & \\
& Non-IBD & $186(49)$ & $118.4(3.9)$ & $11.6(0.4)$ & $12.2(0.4)$ \\
& Crohn's disease & $46(15)$ & $146.7(11.6)^{\star \star}$ & $10.2(1.3)$ & $18.9(2.0)$ \\
& Ulcerative colitis & $34(9)$ & $194.4(16.2)^{\star \star}$ & $12.7(0.9)$ & $15.1(0.9)^{\star \star}$
\end{tabular}

Values are mean $(\mathrm{SEM}), \mathrm{n}=$ number of tissues from $(\mathrm{n})$ subjects. ${ }^{\star \star} \mathrm{p}<0.01$ compared with nonIBD specimens. Tissues bathed in chloride free solutions were not included in this analysis. trophysiological data. A score of 0 corresponded to a normal level of inflammatory cells in the lamina propria, 1 to a mild increase, 2 to a moderate increase, and 3 to a severe increase in the inflammatory infiltrate. ${ }^{20}$ Mast cells were counted using a micrometer grid, fitted in a $10 \times$ eyepiece at a $40 \times$ objective magnification. Four contiguous non-overlapping areas comprising a total of $0.25 \mathrm{~mm}^{2}$ were counted above the muscularis mucosae and four areas of the region below, consisting of the muscularis mucosae and submucosa, also totalling 0.25 $\mathrm{mm}^{2}$, were counted per patient specimen. Mast cell numbers were corrected for square area and are expressed as cell number per $\mathrm{mm}^{2}$ of intestinal tissue.

STATISTICS

Electrophysiological data were compared using Student's $t$ test. In experiments in which there were more than one tissue per patient for a given stimulant, mean Isc values were calculated using both $\mathrm{n}=$ the total number of tissue specimens and $n=$ the total number of subjects (average Isc value determined per subject). In inhibitor experiments, mean Isc responses to stimulation in drug treated tissues were compared with responses in untreated controls obtained from the same patient. Histological data were also compared using Student's $t$ test. Pearson's correlation analysis was used to analyse the relationship between the inflammation score and the Isc response to anti-IgE using SPSS/PC+ statistical package (SPSS Inc., Chicago, Illinois). In all statistical analyses used in this study, $\mathrm{p}<0.05$ was considered significant.

\section{Results}

BASELINE PARAMETERS

Table 1 shows the mean baseline measurements of Isc, PD, and G for IBD and non-IBD large and small bowel groups. Significant increases in the baseline Isc were observed in the IBD groups of large intestine compared with non-IBD tissues, while values were similar in the two groups of small intestinal tissues. Calculated values of tissue conductance were also increased in both Crohn's disease and ulcerative colitis colon compared with nonIBD large intestine.

ISC RESPONSES TO ANTI-IgE STIMULATION

We have previously described the Isc response to rabbit anti-human IgE serum in histologically normal small and large intestine. ${ }^{5} \mathrm{~A}$ similar pattern and time course of response to 10 $\mu \mathrm{g} / \mathrm{ml}$ anti-IgE was observed in non-IBD small and large bowel that consisted of a monophasic rise in Isc which began at about three minutes and peaked at about 10 minutes after adding serum to the antiluminal half of the Ussing chamber (fig 1). Isc responses to an equivalent dose of anti-IgE were significantly reduced in all IBD groups compared with their non-IBD counterparts. As illustrated in fig $1 \mathrm{~A}$, the rise in Isc was delayed and smaller in magnitude in both groups of IBD colon compared with nonIBD large intestine. Peak Isc values (in $\mu \mathrm{A} / \mathrm{cm}^{2}$, as mean (SEM)) in tissues from ulcerative colitis patients were $33 \%$ of values in non-IBD 

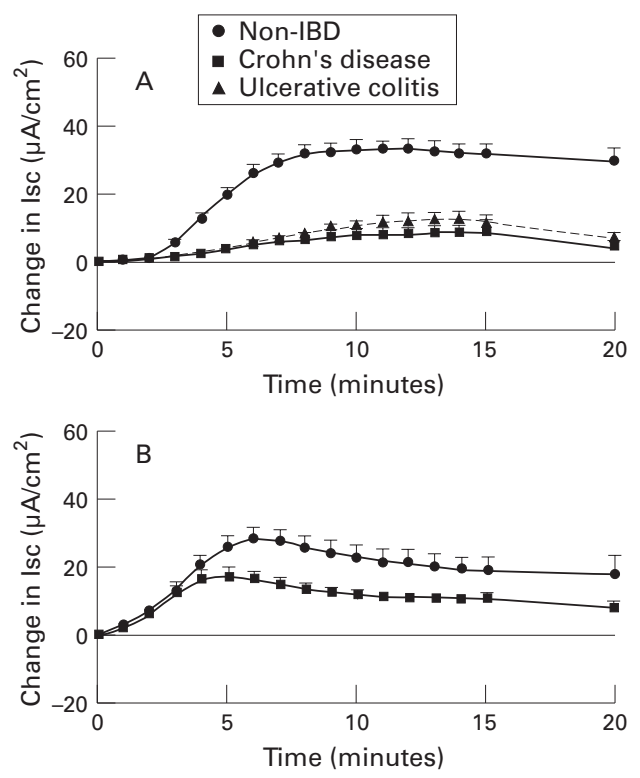

Figure 1: Kinetics of Isc responses to rabbit anti-human IgE serum $(10 \mu \mathrm{g} / \mathrm{ml})$ added to large $(A)$ or small bowel (B) from subjects without IBD, with Crohn's disease (CD), or with ulcerative colitis (UC). For comparison, results (in $\mu \mathrm{A} / \mathrm{cm}^{2}$, mean (SEM)) are shown as if each stimulus was added at time 0 . For large bowel $(A), n=100$ tissues from 48 subjects (non-IBD), 23 tissues from 12 subjects (CD), and 21 tissues from 9 subjects (UC). For small bowel (B), $n=20$ tissues from 9 subjects (non-IBD), and 68 tissues from 30 subjects (CD).

large bowel specimens (13.1 (2.3), $\mathrm{n}=9$ subjects versus 39.9 (3.8), $n=48$ subjects, $\mathrm{p}<0.0005)$ with similar findings in Crohn's disease colon (12.0 (3.7), $\mathrm{n}=15$ subjects, $30 \%$ of non-IBD values, $\mathrm{p}<0.001)$. Differences were less marked between Isc responses to anti-IgE in Crohn's disease and non-IBD small intestine (fig 1B) with the peak Isc value $62 \%$ of non-IBD values (19.3 (3.1), n=30 Crohn's disease subjects; 31.3 (4.8), $\mathrm{n}=22$ non-IBD subjects, $\mathrm{p}<0.05)$. There was no response to control rabbit serum in any group of bowel.

ISC RESPONSES TO HISTAMINE

Isc responses to histamine were more rapid in onset compared with anti-IgE, reaching a maximum Isc less than five minutes after serosal addition in both non-IBD small and large bowel (fig 2). Peak histamine secretory responses (in $\mu \mathrm{A} / \mathrm{cm}^{2}$, as mean (SEM)) were smaller in ulcerative colitis tissues (15.2 (8.4), $\mathrm{n}=3$ subjects) compared with non-IBD colon (39.1 (8.9), $\mathrm{n}=13$ subjects, $\mathrm{p}<0.05$ ) with a more marked reduction in the Crohn's disease large bowel group (6.3 (6.5), $\mathrm{n}=2$ subjects, $\mathrm{p}<0.01$ compared with non-IBD colon). Histamine Isc responses were also decreased in Crohn's disease small bowel (22.4 (8.0), n=7 subjects) but this reduction was not significantly different from non-IBD small intestine (37.4 (8.7), $\mathrm{n}=6$ subjects).

ISC RESPONSES TO FORSKOLIN

Isc responses to forskolin were similar in nonIBD large and small intestine (fig 3). No significant differences were observed in the magnitude of the secretory response to forskolin between ulcerative colitis large bowel or
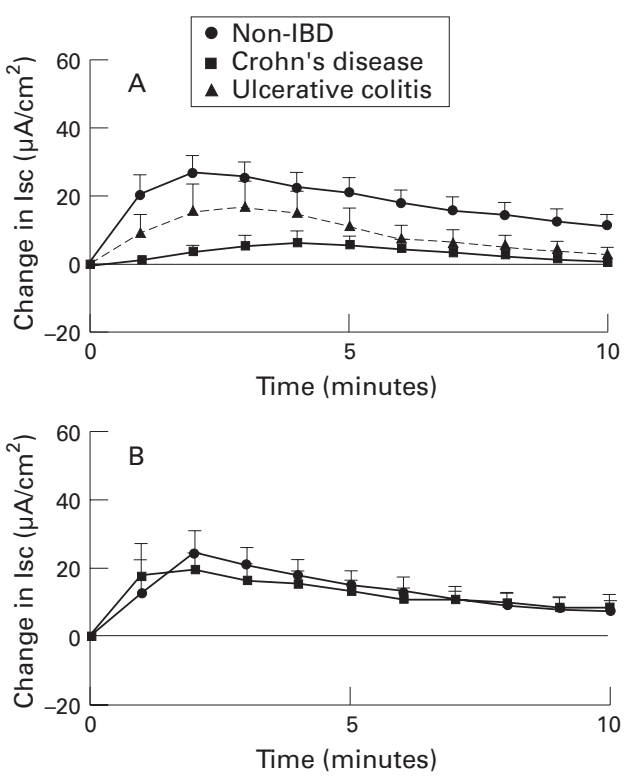

Figure 2: Kinetics of Isc responses to histamine $\left(10^{-4} \mathrm{M}\right)$ added to the serosal surface of muscle stripped large $(A)$ or small bowel (B) from subjects without IBD, with Crohn's disease (CD), or with ulcerative colitis (UC). For comparison, results (in $\mu \mathrm{A} / \mathrm{cm}^{2}$, mean (SEM)) are shown as if each stimulus was added at time 0 . For large bowel (A), $n=33$ tissues from 15 subjects (non-IBD), 4 tissues from 2 subjects (CD), and 9 tissues from 3 subjects (UC). For small bowel, $n=12$ tissues from 6 subjects (non-IBD), and 16 tissues from 8 subjects (CD).

Crohn's disease small bowel groups and their respective non-IBD controls. The forskolin induced peak rise in Isc was reduced in Crohn's disease colonic specimens however.

CHLORIDE FREE BUFFER STUDIES

In both non-IBD large and small bowel, Isc responses to anti-IgE appeared to be largely due to chloride secretion since stimulation in chloride free buffer reduced peak Isc values to $21 \% \quad(n=4$ subjects $/ 8$ tissues per treatment, $\mathrm{p}<0.05)$ and to $17 \%(\mathrm{n}=3$ subjects $/ 6$ tissues per treatment, $\mathrm{p}<0.05)$ respectively of control values in Krebs buffer. ${ }^{5}$ A similar reduction was observed in IBD tissues with Isc responses to

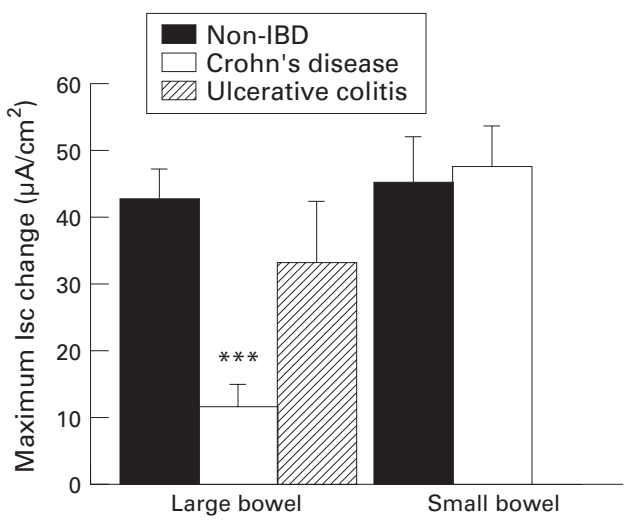

Figure 3: Peak increase in Isc $\left(\mu \mathrm{A} / \mathrm{cm}^{2}\right.$, as mean (SEM)) to forskolin $\left(10^{-5} \mathrm{M}\right)$ compared in large and small intestine from subjects without IBD, with Crohn's disease (CD), or from subjects without IBD, with Crohn's disease (CD), or
with ulcerative colitis (UC). The number of tissues tested for each large bowel group was 75 from 34 non-IBD subjects, 14 from 9 CD subjects, and 12 from 6 UC subjects. In small intestine, 30 tissues from 15 non-IBD subjects and 51 tissues from $24 \mathrm{CD}$ subjects were used. ${ }^{\star \star \star} p<0.001$ compared with non-IBD large bowel. 
TABLE 2 Comparison of baseline electrophysiological parameters in intestinal tissues in chloride containing or chloride free buffer

\begin{tabular}{lllccc}
\hline Specimen site & Pathological condition & Treatment & Isc $\left(\mu \mathrm{A} / \mathrm{cm}^{2}\right)$ & $P D(\mathrm{mV})$ & $G\left(\mathrm{mS} / \mathrm{cm}^{2}\right)$ \\
\hline Small bowel & \multirow{2}{*}{ Non-IBD } & $\mathrm{Cl}+$ & $79.0(28.0)$ & $3.6(1.2)$ & $21.5(2.8)$ \\
& & $\mathrm{Cl}-$ & $27.9(12.2)$ & $2.0(0.7)$ & $13.5(2.9)$ \\
& \multirow{2}{*}{ Crohn's disease } & $\mathrm{Cl}+$ & $63.9(8.0)$ & $3.4(0.5)$ & $23.0(2.5)$ \\
& & $\mathrm{Cl}-$ & $33.3(5.6)^{\star}$ & $2.7(0.4)$ & $14.2(0.9)^{\star}$ \\
Large bowel & \multirow{2}{*}{ Non-IBD } & $\mathrm{Cl}+$ & $140.0(36.4)$ & $15.2(3.2)$ & $8.7(0.7)$ \\
& & $\mathrm{Cl}-$ & $60.6(11.1)^{\star}$ & $15.1(2.2)$ & $7.4(0.4)$ \\
& \multirow{2}{*}{ Crohn's disease } & $\mathrm{Cl}+$ & $156.8(24.1)$ & $13.2(4.1)$ & $22.4(6.0)$ \\
& & $\mathrm{Cl}-$ & $74.1(22.2)^{\star}$ & $9.7(3.7)$ & $18.3(5.6)$ \\
& \multirow{2}{*}{ Ulcerative colitis } & $\mathrm{Cl}+$ & $49.7(9.9)$ & $5.0(1.0)$ & $9.9(0.8)$ \\
& & $\mathrm{Cl}-$ & $17.8(4.8)^{\star}$ & $3.3(0.5)$ & $4.1(1.2)^{\star}$ \\
\hline
\end{tabular}

Values are mean (SEM), $n=3-7$ subjects per group with equal numbers of tissues treated with chloride containing buffer $(\mathrm{Cl}+)$ or chloride free buffer $(\mathrm{Cl}-)$. ${ }^{\star} \mathrm{p}<0.05$ compared with $\mathrm{Cl}+$.

anti-IgE being $11 \%$ of control values in ulcerative colitis large intestine $(n=3$ subjects $/ 6$ tissues per treatment, $\mathrm{p}<0.05)$ and $23 \%$ of control values in Crohn's disease small bowel $(\mathrm{n}=7$ subjects $/ 14$ tissues per treatment, $\mathrm{p}<0.05)$. Table 2 shows the effect of chloride free buffer on basal Isc, PD and G.

HISTAMINE $\mathrm{H}_{1}$ RECEPTOR ANTAGONIST STUDIES In both non-IBD large and small intestine, the peak Isc response to anti-IgE was reduced by over half of control values in the presence of the histamine $\mathrm{H}_{1}$ receptor antagonist, pyrilamine (fig 4). Similar to the results in non-IBD large intestine, pyrilamine reduced Isc responses to anti-IgE to $50 \%$ of control values in ulcerative colitis large intestinal tissues and $42 \%$ of control values in Crohn's disease colon but these differences were not statistically significant. Pyrilamine treatment of Crohn's disease small bowel specimens completely abolished Isc responses to anti-IgE. Our previous studies in non-IBD intestine showed that pyrilamine completely abrogates the Isc response to histamine in human colon and reduces it by $86 \%$ in small bowel. ${ }^{5}$

HISTAMINE DESENSITISATION

When non-IBD large intestinal tissues were pretreated with two serial doses of $10^{-4} \mathrm{M}$ histamine, subsequent stimulation with anti-IgE

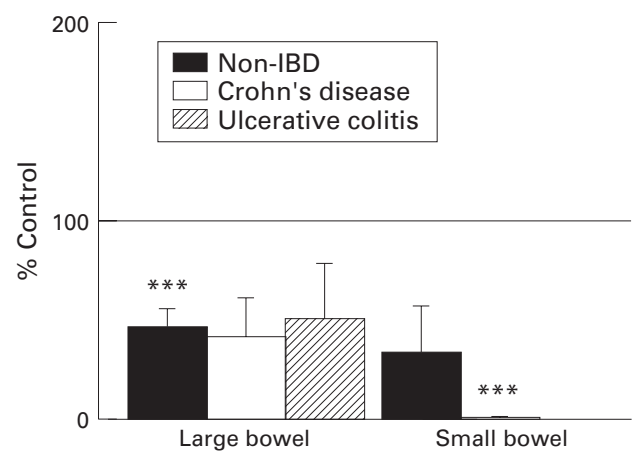

Figure 4: Effect of pyrilamine $\left(10^{-4} \mathrm{M}\right)$ on the maximum Isc response to anti-IgE in large and small bowel from subjects without IBD, with Crohn's disease (CD), or with ulcerative colitis (UC). The mean Isc responses to anti-IgE (calculated on a per subject basis) in drug treated tissues are depicted as a percentage of the mean response to anti-IgE in untreated control tissues of the corresponding category. The SEM are also shown as a percentage of control results. The horizontal line indicates the control values (100\%). Treatment and control groups included 6-26 tissues from 4-14 subjects per category. ${ }^{\star \star *} p<0.001$ compared with control.

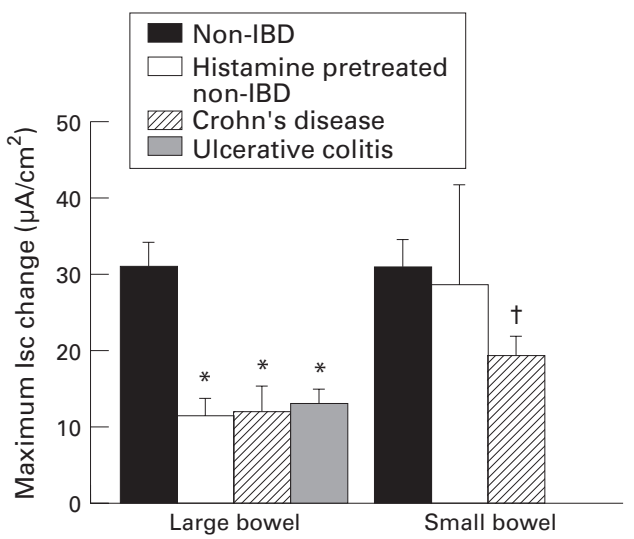

Figure 5: Peak average increases in Isc (in $\mu \mathrm{A} / \mathrm{cm}^{2}$, as mean (SEM)) to rabbit anti-human IgE serum $(10 \mu \mathrm{g} / \mathrm{ml})$ are compared in non-IBD large and small bowel pretreated with histamine $10^{-4} \mathrm{M} \times 2$ and untreated control tissues from the same subjects as well as tissues from subjects with Crohn's disease (CD), or ulcerative colitis (UC). For large bowel, $n=5$ non-IBD, $15 C D, 9$ UC subjects; and for small bowel, $n=3$ non-IBD, $30 \mathrm{CD}$ subjects. ${ }^{\star} p<0.05$ compared with non-IBD large bowel; $t p<0.05$ compared with non-IBD small bowel.

resulted in Isc responses similar in magnitude to those observed in ulcerative colitis and Crohn's disease colon (fig 5). In contrast, histamine pretreatment of non-IBD small intestine had no significant effect on anti-IgE Isc responses.

HISTOLOGY

Table 3 summarises the quantitation of mucosal and submucosal mast cells. Compared with their respective non-IBD control groups, mast cell numbers did not differ in ulcerative
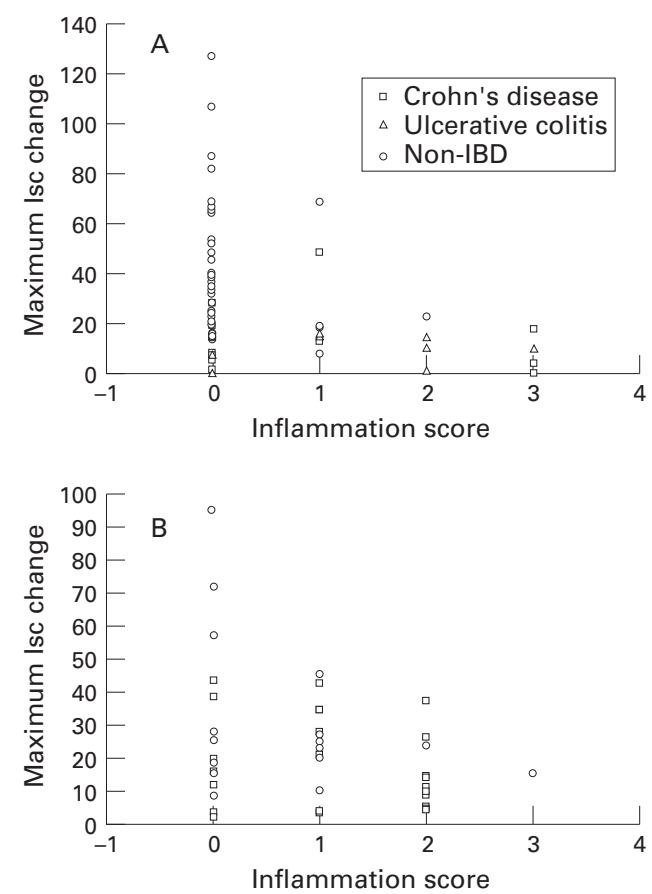

Figure 6: Comparison of individual mucosal inflammation scores and the corresponding mean Isc response to anti-IgE in large $(A)$ and small $(B)$ bowel categorised according to tissue group. Mean Isc values (in $\mu A / \mathrm{cm}^{2}$ ) are plotted against the inflammation score for each patient. No significant differences were detected by Pearson's correlational analysis. 
TABLE 3 Comparison of intestinal mast cell numbers

\begin{tabular}{llccc}
\hline Specimen site & Category & Mucosal & Submucosal & Combined \\
\hline Small bowel & & & & \\
& Non-IBD (19) & $92.7(16.2)$ & $51.9(5.8)$ & $144.6(19.4)$ \\
& Crohn's disease (16) & $188.9(35.5)^{\star}$ & $77.4(11.6)$ & $266.3(43.8)^{\star}$ \\
& & & & \\
Large bowel & Non-IBD (33) & $134.6(14.7)$ & $66.0(6.2)$ & $202.4(19.5)$ \\
& Crohn's disease (4) & $91.3(34.7)$ & $70.0(10.2)$ & $168.8(38.5)$ \\
& Ulcerative colitis (6) & $142.6(49.0)$ & $116.2(28.5)$ & $258.8(75.1)$ \\
\hline
\end{tabular}

Mast cell numbers per $\mathrm{mm}^{2}$ of mucosa, submucosa, and the two areas combined expressed as mean (SEM); $\mathrm{n}$ is the number of subject specimens examined for each tissue category. ${ }^{\star} \mathrm{p}<0.05$ compared with corresponding non-IBD tissues.

colitis or Crohn's disease large bowel but were significantly increased in the mucosa of Crohn's disease small intestine. Inflammation scores ranged from 0 to 3 in each tissue group although the distribution of scores varied within each group (fig 6). Tissues from patients with IBD predominated in the groups of large and small bowel with the higher inflammation scores (see fig 6), but no significant correlation between the degree of inflammation and Isc responsiveness to anti-IgE could be shown within each of the five tissue categories or within colon or small intestine groups using correlational analysis.

\section{Discussion}

Mast cells are a unique population of immune cells resident in the gastrointestinal tract under normal and inflammatory conditions. These cells have been implicated in the pathogenesis of systemic mastocytosis, food allergy, and intestinal parasitic infection, as well as gastrointestinal conditions less clearly associated with mast cells such as inflammatory bowel disease (IBD). ${ }^{7}$ By virtue of the large number of preformed and newly formed mediators that are released in response to a variety of stimuli, ${ }^{121}$ mast cells have significant potential to modulate gut function. In this context, effects on the intestinal epithelium have been best evaluated with evidence that activated mast cells stimulate epithelial ion transport and diminish barrier integrity. ${ }^{7}$ Most of these data have come from animal experiments ${ }^{2-422}$ and to a lesser extent, cultured cell systems. ${ }^{23}$ It is only recently that evidence for mast cell regulation of intestinal ion transport has been shown in human bowel. ${ }^{5}{ }^{6}$ The present study confirms our previous observations that activation of human intestinal mast cells with anti-human IgE serum stimulates a predominantly chloride secretory response involving histamine and shows that mast cell mediated epithelial ion transport is altered in intestine from subjects with IBD. Our results suggest that prior activation of mast cells with release of histamine may account for the reduced secretory response to anti-IgE observed in certain IBD specimens.

In this study ion transport responses to mast cell activation were compared in IBD and nonIBD intestine using antibodies directed to human IgE to crosslink IgE molecules bound to high affinity IgE receptors found on mast cells and basophils. Although some other cells may bear high affinity IgE receptors under certain conditions, the functional significance of this is unknown and thus anti-IgE can be con- sidered a relatively specific stimulus for mast cells. Other agents (concanavalin A, calcium ionophore, ionomycin) known to release histamine from isolated human intestinal mucosal mast cells ${ }^{24}$ were not used because of their potential to act directly on the epithelium or stimulate other immune cells. Anti-IgE induced a predominantly chloride secretory response in all groups of tissues but the magnitude of this response was significantly reduced in small and large intestine from patients with IBD.

Although decreased numbers of mast cells would have explained the diminished epithelial secretory response to mast cell stimulation in IBD intestine, we did not find a reduction in the number of mucosal or submucosal mast cells in any group of IBD tissues compared with the non-IBD controls. No significant differences were observed between any of the colonic groups while mucosal mast cells were increased in Crohn's disease small bowel compared with non-IBD small intestine. Our results are in keeping with the majority of previously published studies which show either increased numbers or unchanged numbers of mast cells in IBD intestinal tissues ${ }^{8-11}$ although other studies have described a reduction in intestinal mast cell numbers in IBD. ${ }^{25}$ The findings in the latter study ${ }^{25}$ and the trend to a decreased number of intestinal mast cells in Crohn's disease colon in the present study may be due to prior degranulation of mast cells which can be difficult to detect by toluidine blue staining. ${ }^{26}$

Another interpretation of our results showing reduced $I \mathrm{sc}$ responses to anti-IgE in IBD tissues is that mast cells in IBD are less responsive to degranulating stimuli or release fewer mediators than mast cells in normal intestine. These possibilities are unlikely since release of histamine, prostaglandin $\mathrm{D}_{2}$, and leukotriene $\mathrm{C}_{4}$ was shown to be increased in anti-IgE activated mast cells from active versus quiescent ulcerative colitis tissues in one study. ${ }^{16} \mathrm{~A}$ recent publication by Bischoff et al also suggests that release of histamine and leukotrienes is increased in stimulated mast cells isolated from actively inflamed intestine of patients with IBD. ${ }^{17}$ Although another study describes similar amounts of histamine being released from anti-IgE stimulated mast cells regardless of whether mast cells were isolated from quiescent IBD intestine, from active ulcerative colitis, or Crohn's disease specimens, or from normal bowel, ${ }^{27}$ there are no reports of reduced mediator release from activated intestinal mast cells in IBD.

Altered epithelial responsiveness to mast cell mediators represents another potential mechanism to account for the reduced Isc responses to mast cell activation and to histamine that were observed in IBD tissues. Previous studies describe altered sodium and chloride transport in colonic segments from patients with colitis. ${ }^{28-31}$ Defects in the biophysical properties of colonic epithelial cell membranes have been proposed as the mechanism(s) responsible for altered ion transport in $\operatorname{IBD}^{30}$ and it is now known that certain cytokines alter epithelial ion 
transport function..$^{32} 33$ The reduced ion transport responses to forskolin found in Crohn's disease colon in this study suggest that the diminished anti-IgE and histamine responses seen in Crohn's colonic tissues may not be specific for mast cell products and could imply a more generalised epithelial defect. Globally altered epithelial transport function does not, however, explain the decreased Isc values seen after anti-IgE or histamine stimulation in ulcerative colitis colon or Crohn's disease small intestine. It is likely that the IBD epithelium reported on in this study represents a relatively less diseased subset compared with previous studies $^{28-31}$ since we excluded tissues with very abnormal basal electrophysiologic properties (baseline Isc failed to stabilise, basal Isc or PD not measurable, response to forskolin absent) from analysis. This premise is supported by the fact that basal Isc values were increased in IBD versus non-IBD colonic tissues in our study while previous studies describe decreased Isc in IBD colon. ${ }^{28-31}$ It is not clear, however, how our small bowel data compare since ion transport has not been well studied in small intestinal inflammation.

There is a substantial body of evidence to suggest that mast cell degranulation is enhanced in IBD. Ultrastructural studies report increased numbers of degranulated mast cells in both ulcerative colitis ${ }^{13}$ and Crohn's disease intestine. ${ }^{12}$ Additional evidence that mast cells may be activated in IBD is provided by reports describing increased levels of histamine in rectal dialysates of patients with ulcerative colitis ${ }^{14}$ or jejunal secretions of patients with Crohn's disease ${ }^{15}$ compared with controls. To test the hypothesis that prior degranulation of mast cells with release of mediators including histamine could account for the reduced anti-IgE and histamine Isc responses observed in IBD intestine, we pretreated non-IBD control tissues with doses of histamine sufficient to prevent subsequent histamine induced secretion. After histamine desensitisation, the magnitude of anti-IgE Isc responses in non-IBD colon was similar to that seen in Crohn's disease and ulcerative colitis colon. This suggests that prior activation of mast cells may have played a role in the reduced colonic ion transport responses to mast cell activation seen in this study. Our results do not suggest that the reduced anti-IgE responses in Crohn's disease small intestine are due to this mechanism although the variation inherent in using a small number of samples may have precluded the detection of a similar phenomenon in the small intestine.

The observation that histamine receptor blockade had no statistically significant effect on anti-IgE responses in IBD colon while pyrilamine completely abrogated the anti-IgE response in Crohn's disease small bowel suggests that the relative amounts of histamine released may differ according to disease site. As we have previously shown that pyrilamine completely abrogates Isc responses to histamine in non-IBD colon, ${ }^{5}$ the lack of significant inhibition of anti-IgE Isc responses by pyrilamine in IBD large intestine, particularly in ulcerative colitis tissues, also supports the concept that lesser amounts of histamine were involved in the epithelial secretory response to mast cell degranulation in IBD colon.

Our study does not address the issue of how mast cells may be activated in IBD. Although the literature supports a role for mast cells in the pathogenesis in IBD it is less clear how they are activated. It has been proposed that food allergens may act as a degranulating stimulus but the evidence for this mechanism occurring in IBD is limited. ${ }^{7}$ IBD intestinal mast cells have also been reported to release histamine in response to intestinal epithelial cell associated components. ${ }^{34}$ Other stimuli that modulate mediator release from intestinal mast cells, including substance $\mathrm{P},{ }^{35}$ chemokines (Crowe et al, unpublished data), and c-kit ligand, ${ }^{17}$ may be increased in IBD and could play a role.

In summary, we have shown that mast cells regulate human intestinal ion transport both under normal conditions and in IBD. Interactions between mast cells and the epithelium appear altered in IBD, reflecting, in part, reduced responsiveness of the epithelium and prior activation of colonic mast cells with release of mediators such as histamine. Further work is needed to explore the role of mast cells in the pathophysiology of inflammatory bowel disease.

We wish to thank the members of the Surgery and Pathology Departments at McMaster University for their cooperation with this project. Michelle Benjamin, Jacqueline Sinclair, and Pam Singh are also recognised for their excellent technical assistance. Eric Clemons and Nina Nguyen are acknowledged for their critical role in data analysis. This study was supported by grants from the Crohn's and Colitis Foundation of Canada, the Medical Research Council of Canada, and the National Institutes of Health (NS 29536).

1 Serafin WE, Austen KF. Mediators of immediate hypersensitivity reactions. $N$ Engl f Med 1987;317:30-4.

2 Crowe SE, Sestini P, Perdue MH. Allergic reactions of rat jejunal mucosa. Ion transport responses to luminal antigen aju inflammatory mediators. Gastroenterology 1990;99:7482 .

3 Perdue MH, Masson S, Wershil BK, Galli SJ. Role of mast cells in ion transport abnormalities associated with intestinal anaphylaxis. Correction of the diminished secretory response in genetically mast cell-deficient $\mathrm{W} / \mathrm{W}^{\mathrm{v}}$ mice by bone marrow transplantation. $\mathcal{F}$ Clin Invest 1991;87:68793.

4 Bern MJ, Sturbaum CW, Karaylacin SS, Berschneider HM, Wachsman JT, Powell DW. Immune system control of rat and rabbit colonic electrolyte transport: role of prostaglandins and enteric nervous system. F Clin Invest 1989;83: $1810-20$.

5 Crowe SE, Perdue MH. Anti-immunoglobulin E-stimulated ion transport in human large and small intestine. Gastroenterology 1993;105:764-72.

6 Stack WA, Keely SJ, O'Donoghue DP, Baird AW. Immune regulation of human colonic electrolyte transport in vitro. Gut 1995:36:395-400.

7 Crowe SE, Perdue MH. Gastrointestinal food hyperCrowe SE, Perdue MH. Gastrointestinal food hyper-
sensitivity: basic mechanisms of pathophysiology. Gastroen-

8 Sommers SC. Mast cells and Paneth cells in ulcerative coliSommers SC. Mast cells and Paneth
tis. Gastroenterology 1966;51:841-50.

9 Rao SN. Mast cells as a component of the granuloma in Crohn's disease. F Pathol 1973;109:79-82.

10 Ranlov P, Nielsen MH, Wanstrup J. Ultrastructure of the ileum in Crohn's disease: immune lesions and mastocytosis. Scand f Gastroenterol 1972;7:471-6.

11 King T, Biddle W, Bhatia P, Moore J, Miner PB. Colonic mucosal mast cell distribution at line of demarcation of active ulcerative colitis. Dig Dis Sci 1992;37:490-5.

12 Dvorak AM, Monahan RA, Osage JE, Dickersin GR. Mastcell degranulation in Crohn's disease. Lancet 1978;i:498.

13 Balazs M, Illyes G, Vadasz G. Mast cells in ulcerative colitis. Quantitative and ultrastructural studies. Virchows Archiv B Cell Pathol 1989;57:353-60.

14 Rampton DS, Murdoch RD, Sladen GE. Rectal mucosal Rampton DS, Murdoch RD, Sladen GE. Rectal mucosal
histamine release in ulcerative colitis. Clin Sci 1980;59: 389-91.

15 Knutson L, Ahrenstedt O, Odlind B, Hallgren R. The jejunal secretion of histamine is increased in active Crohn's disease. Gastroenterology 1990;98:849-54. 
16 Fox CC, Lazenby AJ, Moore WC, Yardley JH, Bayless TM, Lichtenstein LM. Enhancement of human intestinal mast cell mediator release in active ulcerative colitis. Gastroenterology 1990;99:119-24.

17 Bischoff SC, Schwengberg S, Wordelmann K, Weimann A, Raab R, Manns MP. Effect of c-kit ligand, stem cell factor on mediator release by human intestinal mast cells isolated from patients with inflammatory bowel disease and controls. Gut 1996;38:104-14.

18 Veeze HJ, Sinaasappel M, Bijman J, Bouquet J, De Jonge HR. Ion transport abnormalities in rectal suction biopsies from children with cystic fibrosis. Gastroenterology 1991; 101:398-403.

19 Keren DF, Appelman HD, Dobbins WO, Wells JJ, Whisenant B, Foley J, et al. Correlation of histopathologic evidence of disease activity with the presence of immunoglobulin-containing cells in the colons of patients with inflammatory bowel disease. Hum Pathol 1984;15: with inflam $757-63$.

20 Riddell RH. Lewin KJ, Riddell RH, Weinstein WM (eds) Inflammatory bowel diseases. In: Gastrointestinal pathology and its clinical implications. Vol 12. New York: Iguku-Shon, 1992:812-989.

21 Galli SJ. New concepts about the mast cell. $N$ Engl f Med 1994;328:257-65.

22 Crowe SE, Soda K, Stanisz AM, Perdue MH. Intestinal permeability in allergic rats. Nerve involvement in antigeninduced changes. Am F Physiol 1994;27:G617-23.

23 Barrett KE. Immune-related intestinal chloride secretion. III. Acute and chronic effects of mast cell mediators on chloride secretion by a human colonic epithelial cell line. $\mathcal{F}$ Immunol 1991;147:959-64.

24 Befus AD, Dyck N, Goodacre R, Bienenstock J. Mast cells from the human intestinal lamina propria. Isolation, histochemical subtypes, and functional characterization. $\mathcal{F}$ Immunol 1987;138:2604-10.

25 Sanderson IR, Leung KB, Pearce FL, Walker Smith JA Lamina propria mast cells in biopsies from children with Crohn's disease. F Clin Pathol 1986;39:279-83.
26 Bischoff SC, Wedemeyer J, Herrmann A, Meier PN, Trautwein $\mathrm{C}$, Cetin Y, et al. Quantitative assessment of intestinal eosinophils and mast cells in inflammatory bowel disease. Histopathology 1996;28:1-13.

27 Nolte H, Spjeldnaes N, Kruse A, Windelborg B. Histamine release from gut mast cells from patients with inflammatory bowel diseases. Gut 1990;31:791-4.

28 Archampong EQ, Harris J, Clark CG. The absorption and secretion of water and electrolytes across the healthy and diseased human colonic mucosa measured in vitro. Gut 1972;13:880-6.

29 Hawker PC, McKay JS, Turnberg LA. Electrolyte transport across colonic mucosa from patients with inflammatory bowel disease. Gastroenterology 1980;79:508-11.

30 Sandle GI, Higgs N, Crowe P, Marsh MN, Venkatesan S, Peters TJ. Cellular basis for defective electrolyte transport in inflamed human colon. Gastroenterology 1990;99:97105.

31 Jenkins HR, Milla PJ. The effect of colitis on large-intestinal electrolyte transport in early childhood. $\mathcal{F P G N ~} \mathcal{F}$ Pediatr

32 Colgan SP, Parkos CA, Matthews JB, Awtrey CS, Lichtman $\mathrm{AH}$, Delp-Archer $\mathrm{C}$, et al. Interferon-gamma induces a cell surface phenotype switch in intestinal epithelia: downregulation of ion transport function and upregulation of immune accessory ligands. Am f Physiol 1994;267:C40210 .

33 Colgan SP, Resnick MB, Parkos CA, Delp-Archer C, McGuirk D, Bacarra, et al. IL-4 directly modulates function of a model human intestinal epithelium. 7 Immunol 1994;153:2122-9.

34 Fox CC, Lichtenstein LM, Roche JK. Intestinal mast cell responses in idiopathic inflammatory bowel disease. Histamine release from human intestinal mast cells in response to gut epithelial proteins. Dig Dis Sci 1993;38:1105-12.

35 Wang L, Stanisz AM, Wershil BK, Galli SJ, Perdue MH. Substance P induces ion secretion in mouse small intestine through effects on enteric nerves and mast cells. Am $\mathcal{f}$ Physiol 1995;269:G85-92. 